\title{
MENTALNOŚĆ DEMOKRATYCZNA A DOGMATYZM. PRZEMIANY POSTAW SPOLECZEŃSTWA POLSKIEGO W PROCESIE DEMOKRATYZACJI
}

\section{Iwona Jakubowska-Branicka*}

\section{Abstrakt}

Tezą tekstu jest, że życie i wychowanie w totalitarnym społeczeństwie (PRL) nie mogło pozostać bez wpływu na mentalność dużej przynamniej części społeczeństwa. Wielu autorów, zarówno socjologów jak językoznawców i psychologów podkreślało w swoich pracach ten aspekt rzeczywistości stawiając tezę, że funkcjonowanie w świecie wykreowanym przez totalitarny język determinuje i deformuje postrzeganie rzeczywistości i kategorii opisu świata społecznego.

Słowa kluczowe: demokracja, totalitaryzm, jęzүk, mentalność, dogmatyzm, biało-czarny paradygmat

\section{DEMOCRATIC MENTALITY AND DOGMATISM. MINDSET SHIFTS IN THE POLISH SOCIETY DURING THE PROCESS OF DEMOCRATIZATION}

\section{Abstract}

The thesis of the text is, that growing up and surviving in totalitarian society (People's Republic of Poland - PRL) had a profound effect on the mentality of Poles. Many authors - sociologists, linguists, and psychologists alike - have noted that living in a world created by totalitarian language determines and deforms the perception of reality, along with the categories in which the social world is perceived and described. This is precisely what I will argue in this paper.

Keywords: democracy, totalitarianism, language, mentality, dogmatism, white black paradigm

\footnotetext{
* Prof. dr hab. Iwona Jakubowska-Branicka, Uniwersytet Warszawski, Katedra Historii Idei i Antropologii Kulturowej, Warszawa, e-mail: ibranicka@isns.uw.edu.pl
} 
Minęły prawie trzy dekady od momentu, kiedy Polska, po wielu dziesięcioleciach braku autonomii, przymusowej zależności od totalitarnego mocarstwa, odzyskała wolność, stała się państwem demokratycznym i została przyjęta do demokratycznych międzynarodowych instytucji. Najpierw do Rady Europy, potem do NATO i wreszcie do Unii Europejskiej. Przynależność do demokratycznego świata politycznego i możliwość realizacji demokratycznych wartości, zapisanych w prawie praw człowieka były najpierw marzeniem a potem powodem do radości zdecydowanej większości społeczeństwa polskiego, umęczonej totalitarnymi rządami traktującej ludzi przedmiotowo władzy, władzy narzucającej obowiązkowy sposób myślenia, karzącej wszystkich, którzy mieli odmienne od narzuconej „Prawdy” o rzeczywistości zdanie. Życie w PRL-u, podobnie jak życie w pozostałych państwach bloku sowieckiego, było życiem w biało-czarnym paradygmacie, w biało-czarnej narracji o rzeczywistości, w której odstępstwo od oficjalnej „Prawdy” było definiowane jako zło, które trzeba wytępić, protestujący zaś byli określani mianem chuliganów, wichrzycieli burzących porządek, zdrajców ojczyzny, nieprawdziwymi Polakami i podobnymi określeniami.

Życie i wychowanie w takim społeczeństwie nie mogło pozostać bez wpływu na mentalność dużej przynamniej części społeczeństwa. Wielu autorów, zarówno socjologów jak językoznawców i psychologów podkreślało w swoich pracach ten aspekt rzeczywistości stawiając tezę, że funkcjonowanie w świecie wykreowanym przez totalitarny język determinuje i deformuje postrzeganie rzeczywistości i kategorii opisu świata społecznego. Taka jest też teza tego tekstu.

Hanna Arendt (1989), poddając analizie naturę totalitaryzmów w słynnym dziele Korzenie totalitaryzmu wyraża opinię, iż totalitarne ideologie są z założenia dogmatyczne, ponieważ niezależnie od przekazywanych treści opierają się na przeciwstawieniu kategorii „dobra” kategorii „zła”, przy czym dobro definiowane jest poprzez zgodność z propagowaną ideologią, zło, poprzez jakakolwiek tej ideologii krytykę. Podstawowym 
dogmatem ideologii totalitarnej jest, jak pisze Arendt, założenie, że „Świat jest podzielony na dwa gigantyczne, wrogie obozy, z których jednym jest ruch, i że ruch może i musi walczyć z całym światem" (Arendt 1989: 288) - twierdzenie to toruje drogę nieograniczonej agresywności reżymów totalitarnych sprawujących władzę, a dla totalitarnej propagandy bardziej niż groźby i zbrodnie dokonywane na jednostkach charakterystyczne jest stosowanie pośrednich, zawoalowanych pogróżek przeciwko wszystkim, którzy nie przyjmują jej nauk, później zaś masowe morderstwa popełniane na „winnych” i „niewinnych” (Ibidem: 273).

W konsekwencji elementem koniecznym totalitarnej ideologii i propagandy jest figura wroga i wroga obiektywnego. Wrogiem jest każdy, kto nie jest po stronie „dobra”, czyli w „naszym” obozie. Koncepcja wroga obiektywnego jest wyrafinowana w swojej perfidii. Wrogiem obiektywnym jest każdy uznany za „nosiciela tendencji” niezgodnych z oczekiwaniami systemu. Koncepcja wroga obiektywnego jest, zdaniem Arendt, dla systemów totalitarnych niesłychanie użyteczna: „Koncepcja »obiektywnego przeciwnika «, który zmienia się stosownie do okoliczności w ten sposób, że natychmiast po zlikwidowaniu jednej kategorii, można wypowiedzieć wojnę następnej, dokładnie odpowiada rzeczywistej sytuacji powtarzanej bezustannie przez totalitarnych władców. Oznacza to, że ich reżym nie jest rządem w jakimkolwiek tradycyjnym sensie, ale ruchem; jego rozwój napotyka stale nowe przeszkody, które należy usunąć. Jeśli w systemie totalitarnym można w ogóle mówić o jakimś myśleniu w kategoriach prawnych, to »obiektywny przeciwnik « jest jego podstawową konstrukcją” (Ibidem: 323). Wrogiem obiektywnym jest każdy „potencjalnie zdolny” do popełnienia przestępstwa, stąd kolejne pojęcie wprowadzone przez Arendt do teorii: „przestępstwo potencjalne" (Ibidem: 324). 
Również Alain Besançon (1989), francuski historyk, politolog i sowietolog, charakteryzuje ideologie totalitarne jako oparte na przeciwstawieniu „dobra” i „zła”. Wprowadził on pojęcie „gnozy totalitarnej”. Jego zdaniem marksizm-leninizm czy jakikolwiek inny totalitarny sposób myślenia nie jest ani filozofią, ani klasycznie pojmowaną ideologią. Można go natomiast porównywać z towarzyszącym późnemu judaizmowi i rodzącemu się chrześcijaństwu gnostycyzmem, który również cechuje totalitarny sposób myślenia. Gnostycy mieli świadomość upadku starego świata, a w konsekwencji zacierania się granic między dobrem i złem. Celem świata jest absolutne zwycięstwo dobra, a sposobem na wyzwolenie się od zła jest gnoza, czyli poznanie. Dotyczy ono praw świata i człowieka, ich ewolucji, stanu pierwotnego, upadku, dróg odkupienia oraz środków umożliwiających wybawienie od zła. Gnoza umożliwia jednostce prawidłowe rozeznanie w sytuacji i co za tym idzie - wybór dobra. W gnozie wszystkie zjawiska są wytłumaczalne i zrozumiałe, wyprowadza się je bowiem z jednej matrycy, z jednego schematu porządkowania świata. Gnoza może być absolutna jedynie wtedy, gdy jest dogmatyczna, musi bowiem eliminować wszelką krytykę. Jeżeli porównać gnozę religijną do marksizmu-leninizmu, dostrzeżemy szereg podobnych cech. Można do nich zaliczyć nadinterpretację historii, wynikającą z doktryny moralność, powrót do statusu wyznawcy przez samokrytykę, jednostronną ocenę człowieka ze względu na jego możliwość uczestnictwa w zbawieniu, podział na bojowników i masy, definicję bojownika jako tego, który posiadł wiedzę i jest ascetycznym profesjonalistą bez potrzeb życiowych, oraz dualizm geohistoryczny między rejonami skazanymi a ocalonymi. Gnoza totalitarna i religijna bliskie są sobie jedynie pod względem struktur myślenia, stanów ducha i konstrukcji psychicznych. Różni je to, że jedna pasożytuje na religii, druga opiera się na pewności naukowej. Według gnozy totalitarnej świat podzielony jest na strefę dobra i strefę zła. Wszelkie dobro koncentruje się we własnym kraju, rządzonym przez „naszą” partię. Po drugiej stronie 
skupione zostają wszelkie gatunki niedoli i zła. Charakterystyczna dla totalitarnej gnozy jest wiara w świeckie zbawienie, to znaczy stworzenie królestwa szczęśliwości na ziemi. Aby osiągnąć ostateczny cel totalitarnej utopii, konieczny jest bunt i walka z siłami starego, złego świata. Niezależnie od formy i metod walka ta jest szlachetna i dobra, prowadzi bowiem do dobrego celu, w perspektywie przyszłości liczy się tylko całkowite i ostateczne wyzwolenie. Rewolucja może być dokonana jedynie przez przeznaczoną do tego celu grupę, Mesjasza powołanego do wyzwolenia ludzkości. Niezależnie od tego, czy jest to proletariat, rasa aryjska czy też jednostka, która obwołała się wodzem, celem jest zawsze zwycięstwo światowej rewolucji.

Zarówno Arendt, jak i Besançon akcentują manicheizm totalitarnych ideologii. Podstawą manicheizmu jest koncepcja radykalnego dualizmu dwóch zwalczających się odwiecznie praelementów o substancjalnej naturze. Są nimi opozycje: Światłość - Ciemność, Dobro - Zło a w odniesieniu do religii Duch - Materia. Wizja ta wpływa na teorię człowieka i kształtuje zasady moralnego działania. Powinnością człowieka jest walka z ciemnością (Mała Encyklopedia Filozofii 1996). Walka jest nieodłącznym elementem pojęcia manicheizmu. Genezą manicheizmu jest synkretyczna religia założona w III wieku, pojęcie manicheizmu jest jednak stosowane również do opisu pozareligijnych obszarów rzeczywistości. W odniesieniu do omawianego tematu rolę praelementów spełniają opozycyjne ideologie polityczne, głoszone i reprezentowane przez różne ugrupowania polityczne. To właśnie manicheizm wpisany w totalitarne ideologie skłania do uznania ich za dogmatyczne. Dogmat bowiem to twierdzenie uznane za podstawowe i niepodważalne, należące do sfery religii, filozofii czy światopoglądu (Ibidem). Wszystko to, co jest po stronie Światła i Dobra, jest Prawdą.

Analiza języka totalitaryzmów prowadzi, do pozytywnej weryfikacji założeń teorii totalitarnej ideologii przedstawionych przez Arendt i Besançona, pozwala też ideologię i wizję świata totalitarnego bardziej 
szczegółowo opisać i zrekonstruować. Otwiera również nowy rozdział badań nad językiem. Ponury i przerażający w swojej wymowie i skutkach był przedmiotem wielu analiz.

W 1949 roku George Orwell wydał słynną książkę Rok 1984, wprowadzając do literatury i jak się później okazało również do nauki pojęcie nowomowy. Lektura książki wiedzie czytelnika w niezwykły, niewiarygodny i przerażający świat totalnego panowania języka, panowania wyrażającego się całkowitym zdominowaniem myśli a tym samym uczuć bohaterów. Orwell skonstruował koncepcję języka zdolnego całkowicie opanować myślenie jednostki. Pisał: „Celem nowomowy było nie tylko dostarczenie środków odpowiednich do wyrażania światopoglądu oraz myśli właściwych dla zwolenników angsocu, lecz również uniemożliwienie swobody myślenia. Zakładano, że z chwilą gdy nowomowa wejdzie całkowicie do powszechnego użytku, a staromowa ulegnie zapomnieniu, jakakolwiek herezja myślowa - czyli odejście od zasad angsocu - stanie się całkowicie nierealna, przynajmniej jeśli chodzi o ujęcie jej w słowa. Słownictwo nowomowy tak ukształtowano, aby za jego pomocą można było przekazać - ze wszystkimi odcieniami znaczeniowymi - to, co lojalny członek Partii ma do powiedzenia, zarazem zaś uniemożliwiono wykorzystanie języka do formułowania, nawet okrężną drogą, myśli uznawanych za niewłaściwe" (Orwell 2006: 245). Nowomowę skonstruowano nie po to, by zwiększyć, ale przeciwnie - aby zawęzić zakres myślenia. Orwellowska koncepcja znaczenia słowa stała się inspiracją dla wielu teoretyków i badaczy tego zagadnienia w późniejszym okresie. Jego zdaniem, podobnie jak wielu wypowiadających się na ten temat, słowo kształtuje pojęcia a tym samym determinuje myślenie i postrzeganie rzeczywistości przez jednostki.

Pierwszą, klasyczną już, pracą poświęconą analizie języka hitlerowskiego totalitaryzmu jest LTI. Notatnik filologa Victora Klemperera, wydana po raz pierwszy w 1946 roku. Klemperer był niemieckim filologiem żydowskiego pochodzenia. Po przejęciu władzy przez NSDAP 
został pozbawiony katedry uniwersyteckiej i prawa wykładania, jak wszyscy Żydzi został poddany procesowi marginalizacji ze społeczeństwa i prześladowaniom. Tajemniczy skrót LTI oznacza Lingua Tertii Imperii. Jak pisze w pięknej dedykacji poświęconej żonie, Niemce, która uratowała mu życie, książka ta jest ogólną refleksją filologa i pedagoga. Refleksja ta dotyczy zjawisk językowych charakterystycznych dla tego okresu historii. Pojęcie ,język Trzeciej Rzeszy” Klemperer rozumie szeroko, obok zagadnień czysto językowych ma na myśli również formy życia publicznego w Niemczech hitlerowskich, charakter plakatów, krój i barwę mundurów, pozdrowienia nazistowskie (za: Klemperer 1983).

Książka jest efektem pracy autora nad dziennikami, które pisał od pierwszych dni panowania nazizmu do wyzwolenia. Dzienniki te uczynił przedmiotem lingwistycznej analizy już po zakończeniu wojny, ponieważ, jak pisze, dopiero wówczas zrozumiał znaczenie słowa dla wydarzeń, które miały miejsce. W posłowiu zatytułowanym $Z$ powodu wyrazów przytacza rozmowę z Niemką, która była w czasach hitleryzmu skazana na więzienie, a na pytanie: „A z jakiegoż powodu pani siedziała?”, odpowiedziała: „No, z powodu wyrazów (obraziła Führera, symbole i instytucje Trzeciej Rzeszy). To było dla mnie olśnienie. Na dźwięk tego słowa ujrzałem wszystko jasno. $Z$ powodu wyrazów. Wiedziałem już, że z tego samego powodu i dla tego samego celu zabiorę się do dziennika. (...) Tak powstała ta książka" (Klemperer 1983: 303). Olśnieniem było dla Klemperera uświadomienie sobie kreacyjnych i definicyjnych funkcji języka, tego, że to właśnie język kreuje obrazy rzeczywistości.

Według Klemperera siła nazistowskiego antysemityzmu i nazistowskiej nienawiści była w dużej mierze efektem językowej manipulacji. „Narodowy socjalizm wślizgiwał się w ciało i w krew tłumu pojedynczymi słowami, zwrotami, formami zdań, które narzucał przez milion- 
krotne ich powtarzanie i które były przejmowane mechanicznie i nieświadomie. Schillerowski dystych o »kształconym języku, co składa słowa i myśli za ciebie« zwykło się pojmować czysto estetycznie i w sposób, że tak powiem, nieszkodliwy. Udany wers o »ukształconym języku « nie mówi jeszcze nic o poetyckiej potencji tego, kto go złożył; mając do dyspozycji język wysokiej kultury, nietrudno nadać sobie pozór poety i myśliciela. Ale język nie tylko składa słowa i myśli za mnie: kieruje również moim uczuciem, steruje całą moją duchową istotą - tym bardziej, im bardziej bezrefleksyjnie, nieświadomie mu się poddaję. A jeśli ten ukształcony język został utworzony z elementów trujących, albo jeśli zrobiono z niego nosiciela trucizny? Słowa mogą być jak maleńkie dawki jadu: połyka się je niepostrzeżenie, wydają się nie mieć żadnego skutku, a jednak po pewnym czasie następuje trujące działanie. Jeśli ktoś przez dostatecznie długi czas, to co bohaterskie i cnotliwe, nazywa fanatycznym, ten wreszcie rzeczywiście uwierzy, że fanatyk to cnotliwy bohater i że bez fanatyzmu nie można być bohaterem. Słowa »fanatyczny « i »fanatyzm « nie były wynalazkiem Trzeciej Rzeszy: ona tylko zmieniła ich walor i w ciągu jednego dnia używała ich częściej niż inne okresy historyczne przez całe lata. (...) Język nazistowski czerpie wiele swoich słów z zagranicy, większość pozostałych przejmuje od Niemiec przedhitlerowskich. Ale zmienia on walor słów i częstotliwość ich użycia, czyni własnością ogółu to, co dawniej należało do jednostki lub niewielkiej grupy, przywłaszcza na rzecz partii to, co dawniej było własnością ogółu, a przy tym wszystkim nasyca słowa, wyrażenia i formy zdaniowe swoją trucizną, czyni język posłusznym narzędziem swego straszliwego systemu, pozyskuje w języku swój najsilniejszy, najbardziej publiczny i zarazem najtajniejszy środek agitacji. Myślę, że wyraźne ukazanie trucizny zawartej w LTI i ostrzeżenie przed nią jest czymś więcej niż zwykłym belferstwem. Kiedy u prawowiernych Żydów jakieś naczynie stołowe stanie się nieczyste ze względów kulturowych, oczyszczają je w ten spo- 
sób, że zakopują je w ziemi. Wiele słów z nazistowskiego uzusu językowego należałoby na długi czas, a niektóre na zawsze, złożyć w zbiorowym grobie" (Ibidem: 25-26).

Zacytowany obszerny fragment przytoczyłam nie bez powodu. Klemperer wykłada w nim jasno, jak wielkie znaczenie ma język dla myślenia, postrzegania i odczuwania emocji. Co więcej, jest zdania, że monopol językowy „maleńkiej grupy ludzi, a właściwie jednego człowieka” (Ibidem: 32) sprawował władzę absolutną i rozciągał się na całą sferę języka niemieckiego.

Zdaniem Klemperera LTI zmierza do całkowitego pozbawienia jednostki jej indywidualnej istoty, do zagłuszenia w niej osobowości, do uczynienia z niej istoty bezmyślnej i bezwolnej, wpaja metody fanatyzowania i masowej sugestii. Największym sukcesem LTI było to, iż język sprawił, że poniżeni i wykluczeni język ten przejęli, przez co mówili i myśleli o sobie tak, jak ich oprawcy.

Przykładów podawanych i analizowanych przez Klemperera jest wiele, a jego praca mogłaby stać się przedmiotem osobnych dociekań naukowych, podejmujących próbę systematyzacji, której sam autor nie podjął. Nie ulega jednak wątpliwości, że z przeprowadzonych przez niego studiów wyłania się manichejska wizja opisywanego świata. Manicheizm ten wyraża się zarówno w podziale świata na istoty zaliczane do kategorii ludzi i nie-ludzi wedle kryterium rasy, jak i w uznaniu, że prawdziwa jest tylko jedna ideologia, reszta zaś jest kłamstwem i złem. $\mathrm{W}$ tej manichejskiej wizji świata $\mathrm{z}$ definicji obecna jest figura wroga, którego należy unicestwić, a obowiązującą retoryką jest retoryka wojny i zwycięstwa.

Systematyczną analizę języka totalitaryzmu sowieckiego przedstawia uczennica Alaina Besançona Françoise Thom w książce La langue de bois opublikowanej po raz pierwszy w 1987 roku. Termin „drewniany język” (ros. dubowoj jazyk - dosłownie „dębowy język”) w języku rosyjskim oznaczał początkowo styl administrowania carskiej biurokracji. 
Obecnie używany jest zamiennie $\mathrm{z}$ terminem nowomowa, wprowadzonym przez Orwella. We wprowadzeniu do książki Thom pisze, iż drewniany język to taki, który pragnie mieć monopol na prawdę. To, co opisuje, nie istnieje, a to, co jest, stale jest zagłuszane przez to, co powinno być. „Drewniany język to ciąg magicznych zaklęć, przekształcony w łańcuch koniecznych aksjomatów. Dziwność drewnianego języka bierze się z tego, że w odróżnieniu od innych języków pełni tylko jedną funkcję - jest nosicielem ideologii” (Thom 1990: 8).

W przeciwstawieniu grupy MY grupie ONI w całej pełni wyraża się dychotomizacja rzeczywistości właściwa dla narracji budowanej przez drewniany język. Słownictwo drewnianego języka jest nie tylko ubogie, ale dzieli się na strefy wpływów kluczowych idei, analogii-sił, które zaczerpnięto ze zwykłego języka, a które zostały wykorzystane przez drewniany język z uwagi na ich potężne oddziaływanie na umysły i różnorodne możliwości zastosowania.

Zdaniem Thom, zgodnie z pierwszą i najważniejszą z tych idei-sił, świat jest podzielony na dwa przeciwstawne i nie dające się pogodzić obozy. Ta manichejska wizja stanowi niewyczerpane źródło metafor i frazesów, a przede wszystkim organizuje drewniany język. Z tego powodu wiele słów drewnianego języka zaczerpniętych zostało z repertuaru militarnego. Jak pisze Thom, symbolika wojenna rozciąga się nawet na dziedziny tradycyjnie bukoliczne, na przykład gdy mowa o dojeniu krów czy o kopaniu ziemniaków, słyszymy ciągle o frontach, atakach, bataliach, stawianiu oporu, braniu szturmem, strategii, taktyce itd., nawet pokój staje się obiektem zaciekłej walki. Jak podkreśla, owo upodobanie do terminologii wojskowej można odnaleźć również w słownictwie nazistowskim.

Inną konsekwencją dualizmu jest to, że żadne słowo drewnianego języka nie jest „niewinne”. Wszystkie uległy wstępnej interpretacji. Niektóre terminy stosuje się do „złego świata”, który ma sczeznąć, inne są przyporządkowane opisowi grupy MY. Każde pojęcie należy do jednego 
z dwóch obozów i jest określane przez pojęcie przeciwne, zgodnie z podstawową opozycją „nasz - wrogi”. Trzecia osoba zaksjologizowana ONI to zawsze wróg, którego trzeba pokonać i który nigdy nie jest opisywany pozytywnie. Wróg ucieleśnia wszystkie cechy i zasady negatywne. Słowa nie służą do oznaczania, stają się narzędziami klasyfikacji.

Thom szczegółowo analizuje kształt i styl drewnianego języka, centralną kategorią rozważań jest jednak dualizm, który organizuje drewniany język i obraz kreowanego przezeń świata. Podobnie jak Klemperer podkreśla wszechogarniający wpływ takiego języka na myślenie. Fundamentalna opozycja rodzi serię par przeciwstawnych pojęć, między którymi drewniany język przerzuca to, co pragnie unicestwić. Drewniany język wchłania nowe, nawet oporne elementy. Jest to możliwe właśnie dzięki manicheizmowi ideologii. Pozostaje tylko przetłumaczyć na drewniany język wstępną interpretację założoną implicite w każdej manicheistycznej wizji i zastosować tak uzyskaną dwubiegunowość. Tym sposobem nowe przedmioty można włączyć do dawnej koncepcji dualistycznej, by nieprzewidziane elementy mogły zostać włączone do ideologii (Ibidem: 58). Specyfiką drewnianego języka jest przerost kodu będący wyrazem determinującego działania władzy politycznej na język i wolą zdobycia władzy magicznej. Kod (czyli słowo) jest znakiem, a znaki - sygnałami. Słowa wymierzone są przede wszystkim w zachowanie, mają spowodować jakieś działanie. „Jak powiedział J. Goebbels: »Nie mówimy po to, by coś powiedzieć, ale by uzyskać określony efekt «” (Ibidem: 66).

Autorem najpełniejszej analizy języka polskiej propagandy politycznej jest Michał Głowiński (1990). Posługuje się on w odniesieniu do omawianego języka terminem nowomowa. Charakteryzuje właściwości nowomowy w czterech punktach, z których za najistotniejszą uważa pierwszą jej cechę, a mianowicie procedurę narzucania wyrazistego znaku wartości. Znak ten, prowadzący do przejrzystych polaryzacji, nie 
ma prawa budzić wątpliwości, jego punktem docelowym jest zdecydowana, nie podlegająca zakwestionowaniu ocena. Oceny prowadzące do podziałów dychotomicznych często stają się ważniejsze od znaczenia. Znaczenia mogą być niejasne i nieprecyzyjne, oceny muszą być wyraziste i jednoznaczne. W konsekwencji powstaje zjawisko, które autor określa jako luźną semantykę. Znaczenie zostaje podporządkowane ocenie, częstokroć nie jest ważne, co dane słowo znaczy, ważne jest, jakie kwantyfikatory się z nim wiążą: dobry - zły, nasz - obcy, postępowy - wsteczny itd. Nowomowa w dużo większym stopniu niż inne style społeczne składa się z elementów „przeinterpretowanych”. Biorąc pod uwagę wszystkie te elementy, Głowiński nazywa ją językiem jednowartościowym.

Szczególne znaczenie dla propagandy PRL miała kategoria wroga. $\mathrm{Z}$ tradycji stalinowskiej wywodzi się zaostrzenie podziałów dychotomicznych: swój - wrogi, słuszny - niesłuszny itp., z którymi wiążą się wyraziste postawy oceniające. Następstwem kreowania wroga na główną figurę propagandy było radykalne zmilitaryzowanie języka. W języku propagandy kategoria wroga była zarysowana bardzo ogólnie - imperialiści, syjoniści, a więc, jak pisze Głowiński, „wrogowie wszelkiej maści”. Zważywszy, że wróg musi wcielić się w konkretne osoby, lub przynajmniej grupy, pospiesznie i spektakularnie „nominowano” na wrogów wybrane jednostki lub grupy (np. Artur Rubinstein z dnia na dzień zmienił status z „wielkiego Polaka” na „ohydnego syjonistę”) (Ibidem: 66). Celem takich zabiegów jest wyznaczenie osób/grup symboli, ku którym winna się skierować społeczna nienawiść. Symboli łatwych do manipulowania i podkreślających podział na „swoich” i „obcych”. Inną cechą języka propagandy politycznej było tworzenie sztafażu quasi-patriotycznego. Chodziło o zrównanie tego, co komunistyczne, z tym, co polskie, o narzucenie przekonania, że wszelki nonkonformizm jest czynem antynarodowym, a wszystko to, co uznano za uchybienie systemu, 
powstało za sprawą „obcych” (przede wszystkim Żydów). Zgodnie z tradycjami skrajnej prawicy był to „patriotyzm” skierowany przede wszystkim przeciw obcym. W wydanej niemal 30 lat później, w 2009 roku, książce Nowomowa i ciągi dalsze. Szkice dawne i nowe Głowiński proponuje teorię języka nienawiści, którego fundamentalną cechą jest budowanie manichejskiej wizji świata, podziału na dwie przeciwstawiane sobie kategorie: dobra - My i zła - ONI (Głowiński 2009).

Autorzy przytoczonych wyżej analiz podkreślają funkcje kreacyjne języka totalitaryzmu, szczególnie mocno znaczący wpływ obrazu rzeczywistości wykreowanego przez język totalitaryzmu na struktury mentalne jednostki, kategorie, w których postrzega ona i definiuje rzeczywistość. $Z$ analiz języka totalitaryzmów wyłaniają się obrazy rzeczywistości mające wspólne cechy. Najistotniejszą z nich jest manicheizm wyrażający się w restrykcyjnym podziale na „dobro” i „zło” ściśle związany z kategoriami MY i ONI. Z manichejską wizją świata w sposób konieczny współwystępuje figura wroga, z wszystkimi konsekwencjami dotyczącymi jego traktowania. Należy zatem spodziewać się, że totalitarna narracja o świecie spowoduje w podlegających jej jednostkach wykształcenie się struktur poznawczych odzwierciedlających takie właśnie struktury narracji. Manicheizm totalitarnych narracji o świecie pozwala określić je jako z założenia dogmatyczne, ponieważ niezależnie od przekazywanych treści zawsze opierają się na przeciwstawieniu kategorii „dobra” i „zła, przy czym dobro pojmowane jest jako zgodność z propagowaną ideologią, zło zaś, jako jakakolwiek tej ideologii krytyka.

Wpływ totalitarnych narracji na sposób postrzegania i definiowania rzeczywistości podkreślają również psychologowie. Teza współczesnej psychologii głosi, że proces rozumienia świata ma charakter konstrukcyjny a nie reprodukcyjny (Trzebiński 2002). Badania psychologiczne dowodzą, że identyczne dane o pewnym ciągu zdarzeń przekazywane badanym co innego znaczą dla przedstawicieli różnych kultur, są przez nich zapamiętane i rozumiane jako różne historie. Kultura narzuca 
jednostkom porządek interpretowania świata. Ten porządek wynika z faktu, że jednostki posiadają ogólną wiedzę uwarunkowaną kulturowo i przez kulturę przekazywaną. Wiedza ta jest podstawą reguł interpretacji ponieważ tworzy schematy poznawcze. Schemat poznawczy to model pewnego elementu rzeczywistości pełniący wobec niej dwie powiązane ze sobą podstawowe funkcje: reprezentacji rzeczywistości i przetwarzania informacji o tej rzeczywistości. Jeśli przyjąć taki punkt widzenia, mamy do czynienia z sytuacją, która stwarza możliwość pełnej kontroli i sterowania sposobem postrzegania rzeczywistości przez jednostkę, a więc jej myśleniem. To, jak jednostka postrzega i interpretuje rzeczywistość, jest uwarunkowane schematami narracyjnymi, którymi dysponuje, a te są przekazywane jednostce przez kulturę tworzącą narracje o rzeczywistości.

W kontekście powyższej, krótkiej prezentacji totalitarnego paradygmatu kreowanej rzeczywistości, nie budzi zdziwienia fakt, że przystępując do międzynarodowych badań, badacze przyjęli wstępne założenie, iż mentalność ludzi żyjących i wychowanych w państwach tzw. bloku wschodniego jest różna od mentalności ludzi żyjących i wychowanych w państwach tzw. starych demokracji. Przyjęto hipotezę, że ludzie w państwach postkomunistycznych częściej postrzegają i definiują rzeczywistość w biało-czarnym, manichejskim paradygmacie, są bardziej dogmatyczni.

Międzynarodowe badania zostały przeprowadzone na przełomie lat 1995 i 1996 w siedmiu państwach: Stanach Zjednoczonych, we Francji, Hiszpanii, na Węgrzech, w Polsce, Bułgarii i w Rosji, w ramach międzynarodowego projektu badawczego finansowanego przez National Science Foundation [SES 9213237 \& SBR 93 11403].

W każdym z wymienionych państw przeprowadzono badania na próbie reprezentatywnej liczącej około 1000 badanych. Badania prowadzone były przez wyspecjalizowane ośrodki, tam gdzie było to możliwe, przez Gallupa, tam gdzie Gallup nie miał swojego przedstawicielstwa, 
przez inne ośrodki tego typu. Badania w Polsce zrealizował CBOS. W każdym z państw badania przeprowadzone były na dobranej losowo, reprezentatywnej próbie. Narzędziem badań był kwestionariusz wywiadu. Końcowa wersja badań była wynikiem daleko posuniętego kompromisu ze strony wszystkich uczestników projektu. Ostatecznie badania objęły takie problemy jak: dogmatyzm, liberalizm światopoglądowy, legalizm, stosunek do sądów i wymiaru sprawiedliwości, społeczny konformizm, indywidualizm, znaczenie opinii większości dla legitymizacji prawa, relacje władza - jednostka w zakresie wzajemnych uprawnień i obowiązków, tolerancja, prawa jednostki i uprawnienia mniejszości. Badania obejmowały znacznie ponad 100 zmiennych. W lutym 2007 oraz w lutym 2009 roku powtórzyłam interesującą mnie część badań na próbie ogólnopolskiej. Badania, podobnie jak poprzednio, przeprowadzone były przez CBOS, aby w maksymalnym stopniu zagwarantować porównywalność danych. Badania w 2009 roku uzupełnione były o badania przeprowadzone na próbie kontrolnej: badaniami objęto studentów Międzywydziałowych Indywidualnych Studiów Humanistycznych oraz Międzywydziałowych Indywidualnych Studiów MatematycznoPrzrodniczych Uniwersytetu Warszawskiego. W latach 2010, 2011, 2013, 2014 i 2015, również przez CBOS na próbie ogólnopolskiej powtórzyłam badanie ograniczone do dwóch zmiennych: dogmatyzm i liberalizm światopoglądowy. Punktem wyjścia do badań porównawczych przeprowadzonych w Polsce w 2007, w 2009 roku oraz w latach 2010, 2011, 2013, 2014 i 2015 była hipoteza, iż w związku z postępującym w Polsce procesem demokratyzacji i upływem czasu, w badaniach tych respondenci rzadziej będą deklarowali dogmatyzm, a częściej liberalizm światopoglądowy typowy dla respondentów ukształtowanych przez państwa o długich tradycjach demokratycznych. Wybór jako grupy kontrolnej studentów MISH i MISMaP UW nie był przypadkowy. Twórcy teorii z obszaru psychologii polityki, odwołując się do wyników przeprowadzonych przez siebie badań stawiają tezę, że nasilenie dogmatyzmu 
jest odwrotnie proporcjonalne do wykształcenia, szczególnie humanistycznego. Tak więc przyjęłam hipotezę, że studenci MISH i MISMaP UW znacznie rzadziej niż badani w próbie reprezentatywnej dla społeczeństwa polskiego będą deklarowali dogmatyzm.

Termin i związane z nim pojęcie dogmatyzmu wprowadził do psychologii polityki Milton Rokeach (1960). Prowadzone przez niego badania nad dogmatyzmem wyrosły z krytyki koncepcji osobowości autorytarnej zaproponowanej przez T. Adorno, który zdaniem Rokeacha mierzył tylko prawicową formę nietolerancji. Rokeach dowodzi, że człowiek może wyrażać przekonania demokratyczne w treści, np. wypowiadać się przeciwko rasizmowi, lecz jednocześnie pozostawać zamkniętym w sposobie myślenia i nietolerancyjnym dla wszystkich, którzy mają odmienne przekonania. O dogmatyczności systemu przekonań decyduje nie tyle treść poglądów, które się wyznaje, ile sposób, w jaki się je wyznaje. Dogmatyczność to cecha umysłu ujęta w kategoriach stopniowalnych.

Najistotniejsze cechy dogmatyzmu to: 1/ Postrzeganie i definiowanie świata w kategoriach MY/ONI, dychotomizacja rzeczywistości, manicheizm, 2/ Skrajna nietolerancja wobec poglądów odmiennych od własnych, 3/ ONI (mające inne poglądy) są piętnowani jako wrogowie, grzesznicy, odstępcy od „jedynej słusznej prawdy”, a w związku z tym są dyskryminowani i dehumanizowani, 4/ Identyfikacja z absolutnym autorytetem: bezrefleksyjne przyjmowanie za słuszne i prawdziwe wszystkich treści przez niego głoszonych. Nieumiejętność rozróżnienia między oceną treści informacji i oceną źródła informacji, 5/ Skłonność akceptowania wszystkiego, co pochodzi od pozytywnych autorytetów łączy się skłonność odrzucania wszystkiego, co pochodzi od negatywnych autorytetów, 6/ Klasyfikowanie „obiektów” otaczającej rzeczywistości wedle przynależności do grupy skupionej wokół (sympatyków) pozytywnego i negatywnego autorytetu, 7/ Niezdolność do jakiegokolwiek konsen- 
susu i kompromisu z przedstawicielami grupy ONI. Porozumienie traktowane jest jako zdrada i sprzeniewierzenie się własnym wartościom, 8/ Dogmatyzm implikuje nienawiść; sprzyja tworzeniu i głoszeniu ideologii nienawiści, implikuje posługiwanie się językiem nienawiści. W omawianych badaniach dogmatyzm pojmowany był zgodnie z propozycją teoretyczną M. Rokeacha. Nacisk położony został na dwie zasadnicze cechy dogmatyzmu, to znaczy na postrzeganie rzeczywistości w dychotomiczny sposób, w kategoriach prawdy przez duże „P” oraz stopnia gotowości do kompromisu społecznego z tymi, którzy akceptują inny światopogląd.

Na potrzeby analizy dla wszystkich zmiennych zostały utworzone indeksy, w skład których weszły pytania wskaźnikowe dla danych zmiennych. Indeksy zostały wygenerowane na drodze analiz statystycznych.

W skład indeksu dogmatyzm weszły pytania: 1/ Na świecie istnieją dwa typy ludzi: tacy, którzy opowiadają się po stronie prawdy i tacy, którzy są przeciwko prawdzie, 2/ Nie może przetrwać grupa, która pozwala na to, że jej członkowie mają zbyt wiele różnic w poglądach, 3/ Kompromis zawarty z przeciwnikami politycznymi jest niebezpieczny, ponieważ prowadzi zwykle do zdrady własnych pozycji, 4/ Spośród różnych filozofii, które istnieją na świecie, prawdopodobnie tylko jedna jest prawdziwa. Badani proszeni byli o ustosunkowanie się do tych stwierdzeń na skali od „zdecydowanie zgadzam się”, przez „raczej zgadzam się”, „raczej nie zgadzam się” i zdecydowanie nie zgadzam się”. Wskaźnikowe dla wysokiego poziomu dogmatyzmu były odpowiedzi „zdecydowanie” i „raczej” zgadzam się.

W międzynarodowych badaniach przeprowadzonych w 1996 roku uzyskano następujące wyniki - \% wskazuje, ile osób w badanej populacji zajmuje wysokie miejsca na skali dogmatyzmu:

- Bułgaria - 77,9\%

- Rosja - 73,1\%

- Polska - 69,5\% 
- Francja - 59,4\%

- Węgry $-54,2 \%$

- Hiszpania - 35,2\%

- USA - 33,5\%

Zobaczmy teraz, czy częstość deklaracji wskaźnikowych dla dogmatyzmu zmieniła się na przestrzeni ostatnich 20 lat.

- $1996-69,5 \%$

- $2007-66,7 \%$

- $2009-58,0 \%$

- $2010-61,0 \%$

- $2011-65,1 \%$

- $2013-61,0 \%$

- $2014-64,8 \%$

- $2015-62,5 \%$

Studenci MISH i MISMaP deklarowali dogmatyzm znacznie rzadziej: MISH - 4,5\%, MISMaP - 7,7\%.

Zobaczmy teraz, jak przedstawiają się rozkłady dla zmiennej liberalizm światopoglądowy. Liberalizm światopoglądowy został zdefiniowany jako opozycja dogmatyzmu światopoglądowego, tolerancja dla poglądów innych, uznanie ich prawa do swobody, wolności wypowiedzi, prawa do istnienia $\mathrm{w}$ ramach społeczeństwa grup politycznych reprezentujących skrajne poglądy, przekonanie, że podporządkowanie się poglądom większości nie determinuje ładu i sprawiedliwości społecznej.

W skład indeksu liberalizm światopoglądowy weszły pytania: 1/ Lepiej jest żyć w zdyscyplinowanym społeczeństwie, niż pozwolić ludziom na tak dużo swobody, że może to zagrażać porządkowi, 2/ Wolność wypowiedzi jest zbyt kosztowna, jeśli oznacza, że musimy znosić zagrożenie wynikające ze skrajnych poglądów politycznych, 3/ Społeczeństwo nie powinno tolerować poglądów politycznych zasadniczo różniących się od poglądów większości, 4/ Ponieważ demonstracje często powodują dezorganizację i zagrożenie dla porządku, dlatego radykalnym 
i skrajnym grupom politycznym nie powinno się pozwalać na demonstracje. Podobnie jak poprzednio badanych poproszono o ustosunkowanie się do tych stwierdzeń na skali od „zdecydowanie zgadzam się”, przez „raczej zgadzam się”, „raczej nie zgadzam się” i zdecydowanie nie zgadzam się”. Wskaźnikowe dla wysokiego poziomu liberalizmu światopoglądowego były odpowiedzi „zdecydowanie” i „raczej” się nie zgadzam.

- USA - 67,2\%

- Hiszpania - 58,2\%

- Francja - 49,7\%

- Węgry - 26,6\%

- Rosja - 25,3\%

- Polska - 23,o\%

- Bułgaria - 17,2\%

Zobaczmy teraz, czy częstość deklaracji wskaźnikowych dla liberalizmu światopoglądowego zmieniła się na przestrzeni ostatnich 20 lat.

- $1996-23,0 \%$

- $2007-30,9 \%$

- $2009-30,4 \%$

- $2010-31,1 \%$

- $2011-29,2 \%$

- $2013-31,1 \%$

- $2014-28,6 \%$

- $2015-30,2 \%$

Studenci MISH i MISMaP deklarowali liberalizm światopoglądowy znacznie częściej: MISH - 90,3\%, MISMaP - 88,0\%.

Wyniki badań na próbie ogólnopolskiej wskazują, że w stosunku do 1996 roku nieco rzadziej deklarowany jest przez badanych dogmatyzm, około 7\% mniej respondentów udzieliło w 2015 roku odpowiedzi wskaźnikowych dla dogmatyzmu. Nieco częściej jest przez badanych deklarowany liberalizm światopoglądowy: również około 7\% między 1996 a 2015 
rokiem. Nie zmienia to jednak faktu, że w dalszym ciągu ponad $60 \%$ badanych zajmuje wysokie miejsca na skali dogmatyzmu światopoglądowego, a zaledwie niespełna $1 / 3$ badanych wysokie miejsca na skali liberalizmu światopoglądowego. Oznacza to, że prawie 2/3 społeczeństwa polskiego jest skrajnie nietolerancyjna wobec poglądów odmiennych od własnych, postrzega i definiuje rzeczywistość w manichejskim, biało-czarnym paradygmacie a każdy konsensus i porozumienie z osobami i grupami reprezentującymi odmienne poglądy traktuje jako zdradę i sprzeniewierzenie się własnym wartościom. Daleko od wyników badań na próbie ogólnopolskiej odbiegają odpowiedzi udzielane przez studentów MISH i MISMaP UW. Zaledwie 4,5\% studentów MISH i 7,7\% studentów MISMaP udzieliło odpowiedzi wskaźnikowych dla wysokiego miejsca na skali dogmatyzmu, aż 90,3\% studentów MISH i 88\% studentów MISMaP odpowiedzi wskaźnikowych dla wysokiego miejsca na skali liberalizmu światopoglądowego. Pominąwszy wysoki już, w porównaniu z większością społeczeństwa poziom wykształcenia, należy jednak pamiętać, iż próba do badań studentów dobierana była w odmienny sposób, nie była to próba reprezentatywna. Badanie zostało przeprowadzone przy użyciu mediów elektronicznych - kwestionariusz został umieszczony na stronie internetowej. Wszyscy studenci otrzymali list zapraszający do udziału w badaniu, w liście zamieszczony był link do strony, na której został umieszczony kwestionariusz wywiadu. Udział w badaniu był dobrowolny a więc wzięły w nim udział tylko osoby zainteresowane tematem badań. mamy więc do czynienia z zadziałaniem mechanizmu autoselekcji. Ostatecznie w badaniu wzięło udział 154 studentów MISH i 142 studentów MISMaP.

Zaprezentowane wyniki badań są co najmniej niepokojące z punktu widzenia oczekiwań państwa demokratycznego. Współczesna demokracja liberalna jest strukturą, której funkcjonowanie oparte jest na porozumieniu grup, których przedstawiciele mają różne systemy wartości 
i związane z nimi oczekiwania. Sens współczesnej demokracji leży właśnie w liberalnej umowie społecznej, w konsensusie, który z definicji, nigdy nie jest w pełni satysfakcjonujący dla żadnej ze stron, ale każdej ze stron porozumienia umożliwia godne życie w pokoju i tolerancji. Jeżeli uzupełnimy ten obraz o informację, iż we wszystkich populacjach w badaniach międzynarodowych i we wszystkich badaniach w Polsce dogmatyzm jest dodatnio skorelowany z konformizmem społecznym (w Polsce: 63,2\% w 1996 roku, 54,9\% w 2007 roku, 58,4\% w 2009 roku zajmuje wysokie miejsca na skali konformizmu społecznego); legitymizacją, oparciem oceny słuszności prawa na opinii większości (w Polsce: (70,3\% w 1996 roku, 56,3\% w 2007 roku, 58,9\% w 2009 roku uzależnia słuszność prawa od opinii większości) oraz negatywnie skorelowany z legalizmem, czyli opinią że prawa należy bezwzględnie przestrzegać, prognozy dla utrzymania i rozwoju demokracji w Polsce stają się jeszcze bardziej pesymistyczne. Podstawowym warunkiem, który bezwzględnie musi być spełniony, aby można było powiedzieć, że państwo jest państwem demokratycznym, jest zasada rządów prawa, ale nie prawa narzuconego przez rządzącą większość, a prawa opartego na liberalnej umowie społecznej. Inaczej mamy do czynienia z tyranią większości, czyli zaprzeczeniem demokracji, jak to miało miejsce w faszystowskich Niemczech czasu hitleryzmu, gdzie większość wybrana wedle demokratycznych procedur narzuciła prawo łamiące prawa mniejszości. Demokracja to nie władza większości, a władza większości ograniczona prawami mniejszości, taką też perspektywę przyjęto za podstawę międzynarodowego prawa praw człowieka, aby zapobiec możliwości powtórzenia sytuacji zbrodni ludobójstwa w imię prawa. $Z$ tego powodu współczesna demokracja odrzuciła zasadę absolutnego pozytywizmu prawnego na rzecz praw człowieka.

W kontekście powyższych rozważań, należy postawić pytanie, co można zrobić, jakich użyć środków i instrumentów społecznych, aby do- 
prowadzić do obniżenia poziomu dogmatyzmu w społeczeństwie polskim. Nie bez powodu większość tego tekstu poświęciłam opisowi paradygmatu totalitarnej rzeczywistości, technik jej kreowania oraz konsekwencji życia w takim paradygmacie.

Przerwanie błędnego koła spuścizny totalitaryzmów wydaje się prawie niemożliwe. Moja hipoteza zakładająca, że narzucenie przez liberalne, demokratyczne prawo ram życia społecznego wpłynie na sposób postrzegania i definiowania rzeczywistości przez podmioty tego prawa nie znalazła pozytywnej weryfikacji, a jeżeli to bardzo słabą.

Ludzie wychowani w totalitaryzmie, w manichejskiej rzeczywistości mentalnie w takiej rzeczywistości funkcjonują, taką mają strukturę poznawczą. Uporczywość podporządkowania takim strukturom trafnie opisuje Francoise Thom: „Specyficzne działanie drewnianego języka przejawia się w bezprecedensowym fakcie, że myślenie i mówienie są jednakowo podporządkowane owemu pragnieniu umiejscowienia w społeczeństwie. Składają się one z sygnałów lub oznak wskazujących na przynależność do obozu dobrych. Obywatele sowieccy mają skłonność do niedoceniania roli drewnianego języka, gdyż nie dostrzegają głębokiej destrukcji myślenia, jaką on powoduje. Nie zdają sobie sprawy z tego, że złudzenie łatwego myślenia, jakie stwarza automatyczne mówienie, trwa nawet wówczas, gdy przestało się wierzyć w jego stwierdzenia. [...] Jeśli z tego punktu widzenia analizuje się dzieła dysydentów, to można zauważyć, że do nielicznych należą ci, którzy zdołali uniknąć manicheizmu. Większość z nich zadawala się odwracaniem wartości, które drewniany język łączy ze słowami. To co zostało oznaczone znakiem dodatnim w ideologii marksistowsko-leninowskiej, staje się ujemne i vice versa. Stąd odraza do materializmu, uwielbienie tego co duchowe, uwielbienie narodu jako całości mistycznej itd." (Thom 1990: 91). Zaprezentowane wyniki badań sprawiają, iż trudno oprzeć się refleksji, że mechanizm opisany przez Thom w odniesieniu do społeczeństwa rosyjskiego, dotyczy również społeczeństwa polskiego. 
Czy zamknięty krąg zniewolenia w manichejskim paradygmacie będzie trwał nadal? To zależy tylko od nas, od tych, którzy kreują obrazy rzeczywistości społecznej i od tych, którzy bezrefleksyjnie pozwalają sobie biało-czarny paradygmat narzucić. Życzmy sobie powodzenia dla życia w demokratycznym świecie ${ }^{1}$.

Literatura

Arendt H. (1989), Korzenie totalitaryzmu, Niezależna Oficyna Wydawnicza, Warszawa

Besançon A. (1989), Pomieszanie języków i inne szkice, Wszechnica Społeczno-Polityczna, Kraków

Głowiński M. (1990), Nowomowa po polsku, Wydawnictwo PEN, Warszawa

Głowiński M. (2009), Nowomowa i ciągi dalsze. Szkice dawne i nowe, Universitas, Kraków

Jakubowska-Branicka I. (2016), Hate narratives. Language as a tool of intolerance, Peterr Lang, Frankfurt am Main

Klemperer V. (1983), LTI. Notatnik filologa, Młodzieżowa Agencja Wydawnicza, Warszawa

Mała encyklopedia filozofii (1996), (red. nauk.) Jedynak S., Oficyna Wydawnicza Branta, Bydgoszcz

Orwell G. (2006), Rok 1984, Agora SA, Warszawa

Rokeach M. (1960), The Open and Closed Mind. Investigations into the nature of belief systems and personality systems, Basic Books, New York

Thom F. (1990), Drewniany język, Wydawnictwo CDN, Warszawa

'W tekście wykorzystałam fragmenty mojej książki (2016) Hate narratives. Language as a tool of intolerance. 
Mentalność demokratyczna a dogmatyzm. Przemiany postaw społeczeństwa polskiego w procesie ...

Trzebiński J. (2002), Narracja jako sposób rozumienia świata, Gdańskie Wydawnictwo Psychologiczne, Gdańsk 